\title{
Thymic Damage
}

National Cancer Institute

\section{Source}

National Cancer Institute. Thymic Damage. NCI Thesaurus. Code C118258.

Anatomic injury or physiologic dysfunction of the thymus gland. 